\title{
Arbitrating Employment Disputes Involving International Organizations
}

\author{
Rishi Gulati and Thomas John*
}

\begin{abstract}
This chapter argues that international arbitration needs to be used more frequently in resolving employment-related disputes of international organizations. Especially in the context of claims against international organizations which tend to possess functional immunities, arbitration can play a significant role in ensuring that individuals raising employment claims against them have access to fair trial-compliant modes of dispute resolution. However, this chapter also submits that any arbitral regime must be implemented in good faith. And crucially, without implementing a robust arbitral framework that takes into account the particularities involved in international administrative dispute resolution, any arbitral mechanism is unlikely to fully yield the inherent advantages of arbitration over litigation before traditional international administrative tribunals. Finally, using the example of the arbitral scheme recently implemented by the Hague Conference on Private International law, this chapter provides a potential blueprint for other international organizations.
\end{abstract}

\section{Introduction}

International arbitration is much talked about but little used as a forum of choice to resolve employment-related, or similar, disputes of international organizations - 'international administrative disputes'. This must change. Firstly, international administrative tribunals (IATs) are under ever-increasing workloads and serious delays in the administration of justice to staff members is much too common. It is trite to say that 'justice delayed is justice denied'. Second, there has been an exponential rise in the number of consultants and

* Rishi Gulati, Barrister at the Victorian Bar, Australia and Fellow in Law at the London School of Economics and Political Science (LSE), rishi.gulati@vicbar.com.au; Thomas John, Founding Partner and International Legal Consultant at Grotius Chambers, The Hague, the Netherlands, thomas.john@grotiuschambers.com 
contractors engaged by international organisations (IOS) who neither have access to IATs, nor to national courts, given IOs' immunities. Of course, the situation faced by this latter category of individuals is especially precarious. At the outset, it is clarified that it is not our intention to conduct a legal analysis on how personnel working for Ios should be categorized (in other words, the traditional dichotomy between 'staff members' and 'contractors'), but simply to suggest the role international arbitration can play in enhancing access to justice for all individuals working for IOs, regardless of how an IO may choose to characterize employment status. To further this aim, we highlight why international arbitration needs to be used more frequently in resolving international administrative disputes.

Following this introduction, we commence by discussing the advantages arbitration can yield (Section 2). Especially in the context of claims against IOs, international arbitration can play a significant role in ensuring that individuals raising employment claims against Ios have access to fair trial compliant modes of dispute resolution (Section 3). However, any arbitral regime must be implemented in good faith (Section 4). Finally, we argue that without implementing a robust arbitral framework that takes into account the particularities involved in international administrative dispute resolution, any arbitral mechanism is unlikely to fully yield the benefits identified. Using the example of the arbitral scheme recently implemented by the Hague Conference on Private International Law ( $\mathrm{HCCH}$ ), an Io headquartered in The Hague, we provide a potential blueprint for other organizations (Section5).

Arbitration is typically understood as a "non-judicial process for the settlement of disputes where an independent third party—an arbitrator-makes a decision that is binding". The resolution of disputes through arbitral processes dates back to ancient Greek and Roman times, and has been practiced in one form or another in all cultures around the world. ${ }^{2}$ In modern times, especially when it comes to resolving international disputes, the arbitral process has been highly institutionalized, albeit ad hoc arbitrations occur from time to time. International arbitrations are now mostly administered by well-established

1 CIArb, 'Arbitration'.

2 Kidane 2017, 24-26. 
arbitral institutions, ${ }^{3}$ with arbitrators performing their role in a manner similar to judges, with heavy reliance on past cases. ${ }^{4}$

International arbitration has been used to resolve all manner and form of claims, ranging from typically private disputes (including large-scale commercial disputes), to disputes having a public dimension (especially in the context of investor-State arbitration), as well as employment disputes. ${ }^{5}$ Therefore, arbitral tribunals can be used to resolve a large variety of disputes, including international administrative disputes, should all parties to a dispute agree to do so. Moreover, international arbitration possesses some inherent advantages over traditional litigation. The key advantages include neutrality (staying out of national courts); informality and flexibility (arbitral procedures being less cumbersome than traditional court litigation and existence of party control); speed of the delivery of justice; and crucially, enforceability of arbitral awards through the regime of the Convention on the Recognition and Enforcement of Foreign Arbitral Awards, commonly known as the New York Convention, 1958, which has meant that, subject to some exceptions, arbitral awards can be enforced transnationally with relative ease. All those advantages have been subjected to much commentary and there is no need to precis that discussion here.

However, international arbitration has come under some backlash in recent times due to ever-increasing costs associated with arbitrations; issues of opaqueness especially where disputes have a public or administrative law character (such as the case with investor-State disputes); and concerns about the independence and impartiality of arbitrators. Indeed, commentators tend to be either strong supporters of arbitral processes (the pro-arbitration lobby), ${ }^{6}$

3 The International Chamber of Commerce is one prominent arbitral house; the International Centre for the Settlement of Investment Disputes (ICSID) is best known for investment arbitration; for a discussion of the role of global and regional centres, see Stone Sweet and Grisel, The Evolution of International Arbitration: Judicialization, Governance, Legitimacy 2017, 49.

4 See Stone Sweet and Grisel, 'The Evolution of International Arbitration: Delegation, Judicialization, Governance' 2014, 32 and 43.

5 International commercial arbitration is a forum of choice for resolving large scale crossborder commercial disputes. Parties can include States and Ios as well. Investment arbitration (such as pursuant to the ICSID Convention) is a forum of choice to resolve investment claims (having significant public law elements) between private persons and States; see Menon 2015, 230. Employment disputes are also increasingly being subjected to arbitration where a claim has connections with more than one legal order; see generally, PCA, Labour Law Beyond Borders 2003 .

6 Advocates of international arbitration point to the enforceability of awards across jurisdictions, avoidance of national jurisdiction, flexibility and ability to select arbitrators as its key advantages; see Kidane 2017, 26. 
or strongly oppose it, referring to it as a 'mafia' comprising of a limited number of repeat players that arbitrate most major disputes. ${ }^{7}$ Putting that sharp contrast to one side, we consider that whether arbitration is a desirable mode of dispute resolution or not, depends on the context and nature of the dispute to be resolved. More importantly, how an arbitral scheme is implemented is likely to ultimately determine whether it provides for an effective dispute resolution forum. We treat the debate on arbitration as a means to an end-that is, as a framework that can help secure the effective administration of justice-as opposed to an end in its own right. As we argue in the next section, in the context of international administrative claims, international arbitration can play a significant role given the particularities at play. Provide Reasonable Alternative Means of Dispute Resolution

The fact that Ios have an internationally binding obligation to provide for "appropriate modes" or "reasonable alternative means" of dispute resolution is not contested. ${ }^{8}$ If such an obligation is not complied with, an Io's immunity may be breached, for this may result in an impermissible interference into the right to a fair trial. As the European Court of Human Rights has said:

[A] material factor in determining whether granting [an Io] immunity from $[. .$.$] jurisdiction is permissible under the Convention is whether the$ applicants had available to them reasonable alternative means to protect effectively their rights under the Convention. ${ }^{9}$

Obviously then, the obligation to provide reasonable alternative means of dispute resolution is necessary to ensure compliance with the right to access a fair trial, and from the perspective of the Io, there are strong incentives to provide such alternatives. Failure to do so may open up an Io to the exercise of national jurisdiction. In this respect, Ios justifiably wish to stay out of national courts, fearing intrusions into their independence. Therefore, international arbitration can readily provide for a forum of choice in claims against IOs given that one key advantage of arbitration is its ability to avoid the parties having to litigate claims before national courts. ${ }^{10}$ An arbitral process can indeed form an

$7 \quad$ See Michaels 2014, 53-54.

8 See, for example, General Convention, s 29.

$9 \quad$ ECtHR, Waite and Kennedy $v$ Germany 1999, para 68.

10 See Kidane 2017, 99-100; Caron and others (eds) 2016, 1. 
adequate mode of dispute settlement. As early as 1954, in its Effect of Awards Advisory Opinion, the International Court of Justice said that private persons affected by Io conduct (in that case, it was UN employees) may be delivered justice through a judicial mechanism or through arbitral means, drawing a functional equivalence between courts and arbitration. ${ }^{11}$ In more recent times, the European Court of Human Rights has accepted that arbitration can satisfy the Io's obligation to provide for reasonable alternative means of dispute resolution. ${ }^{12}$

Since Ios generally wish to stay out of national courts, adopting an arbitral mechanism should be an ideal vehicle for Ios to fulfil their access to justice obligations. More specifically, where justice at IATs is noncompliant with fair trial standards, for example, as a result of undue delays in the delivery of justice, arbitral procedures could be a supplement. Albeit, the specific mechanics of how such enhanced choice is implemented will require careful consideration to avoid parallel proceedings and the risk of inconsistent decisions. As we said at the outset, the possibility of arbitration is especially relevant to the large number of individuals engaged by IOs (contractors and consultants) who do not have access to IATs at all. For this category of individuals, international arbitration will then be the only means to access reasonable alternative means of dispute resolution. Clearly, arbitration can play a significant role in international administrative dispute resolution. However, should an arbitral framework be adopted, its success depends on how it is ultimately implemented, a matter on which the remainder of this chapter focuses on.

If an arbitral framework is chosen as a forum of choice, it must be implemented in good faith. Without such a good faith implementation, the regime will fail to provide for reasonable alternative means of dispute resolution. Unfortunately, the Io experience with arbitration has been characterized by the appearance of a lack of good faith, manifesting itself in several forms. ${ }^{13}$ Three points may be made.

Firstly, significant issues can arise in relation to the enforcement of the award. Given that one key strength of the international arbitral regime is the enforceability of awards, any lack of certainty in this respect can reduce

\footnotetext{
11 ICJ, Effect of Awards 1954, 57.

12 ECtHR, Klauseckerv Germany 2015, para 76.

13 The principle of good faith includes acting honestly, fairly and reasonably. It also prohibits the abuse of rights; see International Law Association, 'Berlin Conference' 2004, 11.
} 
the effectiveness of the system. Regarding this important issue, national courts have tended to take inconsistent approaches on whether consent to arbitrate also results in a waiver of immunities from enforcement. ${ }^{14}$ Recent developments have, however, indicated that where an Io enters into an arbitral agreement, any resulting award may be enforced against the IO. ${ }^{15}$ Be that as it may, given the uncertainty on the issue of enforcement, in the absence of an express clause in the arbitration agreement removing an Io's immunity from enforcement in respect of the award in question, a private party can have little confidence that arbitration will be an effective way to resolve claims against Ios given the lengths (and associated costs) to which they may be required to seek enforcement. In this context, the lack of good faith shown by IOs in implementing arbitration becomes even more apparent when the practice of some key Ios is considered. Taking the example of the United Nations (UN), on the bases of only two arbitrations, the UN determined that arbitration is not financially viable. ${ }^{16}$ Yet, it continues to include an arbitration clause in its general conditions of contracts. ${ }^{17}$ In those conditions, the UN also includes a provision that submission to arbitration does not amount to a waiver of UN immunities. ${ }^{18}$ Whether or not courts will hold this provision to be valid is a separate matter - the point being that a private person can have little confidence that even if they succeed in an arbitration, the award will be enforced.

Second, apparent lack of good faith on the part of some ios is confirmed and demonstrated by the arbitration experience specifically in the employment sphere. For example, in one case, the defendant Io (UNESCO) refused to appoint an arbitrator despite entering into an arbitration agreement with one of its personnel. The French courts came to the rescue of the claimant by exercising jurisdiction over the Io, holding that the arbitration agreement waived

14 See Fox and Webb 2015, 394-400.

15 Relying on French jurisprudence, where an Io refused to honour an arbitration award against it concerning a dispute about rental payments, a Lebanese court categorically held that an agreement to arbitrate waived any Io immunities from enforcement; see Obeid Law Firm, 'Arbitration and Immunity from Execution', 10 April 2014, citing Lebanese Execution Bureau decision dated 18 July 2013; also discussed in Mansour, 19.

16 UN, 'Report of the Secretary-General' 2010, paras 168 and 170-172.

17 See UN, General Conditions of Contracts for the Services of Consultants and Individual Contractors 2013, s 16 .

18 This is the case regardless of the subject matter of the dispute. For the purported applicability of UN immunities even where arbitration is entered into, see Ibid., s 17; for other cases, a standard clause used by the UN in all its contracts was noted in UN, 'Report of the Secretary-General' 1995, para 6 ("Nothing in or relating to this Contract shall be deemed a waiver of any of the privileges and immunities of the United Nations, including, but not limited to, immunity from any form of legal process"). 
its immunities. ${ }^{19}$ However, in another case, national courts did not come to the claimant's aid. In a case that ultimately reached the European Court of Human Rights, a candidate was denied a job at the European Patent Office (EPO) based on their disability. ${ }^{20}$ The aggrieved party approached the EPO's internal review mechanism to challenge this allegedly discriminatory treatment, however, the EPO dismissed their claims for lack of standing. ${ }^{21}$ The EPO suggested to the claimant that they may approach the Administrative Tribunal of the International Labour Organization (ILOAT) even though it was clear that the claimant did not possess standing for they were not an EPO employee, a pre-condition to standing before the ILOAT. ${ }^{22}$

The claimant approached German courts arguing that their right to access to a court had been breached as they could neither access justice within the EPO, nor at the ILOAT (for lack of standing); and that the EPO had unlawfully discriminated against him. ${ }^{23}$ German courts refused to lift the EPO's immunities. ${ }^{24}$ The complainant then filed a claim before the ILOAT. The Tribunal unsurprisingly determined that the complainant did not possess standing because it was only open to individuals already employed at the EPO. However, it took a dim view of the EPO's conduct, urging it to submit the dispute to arbitration given the legal vacuum that the claimant faced. ${ }^{25}$ Following the ILOAT's decision, after two years of litigation, the EPO offered the claimant the possibility to arbitrate. ${ }^{26}$ While the claimant was willing to enter into an arbitration that protected their due process rights (right to a public hearing without undue delay), they did not agree to do so on the terms the EPO offered. ${ }^{27}$ The arbitration never eventuated.

The claimant subsequently approached the European Court of Human Rights lodging a claim against Germany arguing that the EPO had failed to provide them with reasonable alternative means of dispute resolution. Without analyzing the overall circumstances of the claim where significant delays had already occurred (more than three years had passed since the claimant first

19 Court of Appeal of Paris, UNESCO v Boulois 1998.

20 See ECtHR, Klausecker $v$ Germany 2015, paras 4-8. The organization stated that at some unknown time in the future, the applicant may not be able to perform their job due to their disability, and that purportedly justify refusing the candidate the relevant job for which they were found to be otherwise suitable.

21 Ibid., para 10.

22 Ibid., para 11.

23 Ibid., para 12.

24 Ibid., paras 14-16.

25 Ibid., paras 19-20.

26 Ibid., paras 21-22.

27 Ibid., para 25. 
approached the EPO), the European Court dismissed the claimant's contentions, holding that the belated offer of arbitration constituted reasonable alternative means. ${ }^{28}$ In the final analysis, over a period of 10 years, a job applicant who was possessed with allegations of discrimination by the EPO approached four dispute resolution forums (the IO itself, German courts, ILOAT and the European Court), being rejected jurisdictionally by each one of them. One may query whether this belated offer to arbitrate in fact is capable of constituting a reasonable alternative means given the delays that had already occurred.

Finally, and perhaps most concerningly, IOs may choose to agree on an arbitration clause simply to oust the jurisdiction of an IAT. For example, at the ILOAT, individuals categorised as non-staff members (such as contractors to an IO) may not access the ILOAT if that tribunal is not expressly selected as a choice of forum in the contract. In its case law, where no alternative mechanisms for such individuals exist, the ILOAT has taken jurisdiction to ensure that access to justice is maintained. ${ }^{29}$ However, where an arbitral mechanism purportedly exists, the ILOAT refuses to take jurisdiction. ${ }^{30}$ This the ILOAT does without satisfying itself that the arbitral mechanism is in fact implemented. Such an approach has resulted in the outcome that an Io can oust the jurisdiction of the ILOAT simply by incorporating an arbitration clause in the contract of individual services.

At the UN, it is worth noting that the now discontinued UN Administrative Tribunal did take jurisdiction over cases advanced by certain claimants on the basis that without its intervention, the claimants would suffer a denial of justice. ${ }^{31}$ However, the present-day United Nations Dispute and Appeals Tribunals have not taken the same approach. It bears mentioning that in respect of its consultants and contractors, the UN provides the possibility of arbitration. However, there is no evidence that such arbitrations are actually conducted. The record is poor. As has already been pointed out, there is evidence of only two arbitrations ever being carried out. ${ }^{32}$ Tellingly, where a UN agency had not appointed an arbitrator despite the presence of an arbitration clause, the French Courts asserted jurisdiction over the defendant international organization on the basis that jurisdictional immunity was waived. ${ }^{33}$

28 Ibid., para 76 .

29 See the broad interpretation given to the term 'staff member' by the ILOAT (an approach not adopted at the UN tribunals) in the well-known case of Chadsey $v$ World Postal Union (now UPU) 1968.

$30 \quad$ See for example ILOAT, J.-D. M. v ILO 2010, consid 6.

31 See UN Administrative Tribunal, Teixeira $v$ Secretary-General of the UN 1977.

32 UN, 'Report of the Secretary-General' 2010, para 146.

33 See Court of Appeal of Paris, UNESCo v Boulois 1998. 
What is apparent is that a carefully crafted dispute resolution framework ought to be implemented if an arbitral regime is to have any prospects of providing for a reasonable alternative means of dispute resolution. Below, through the example of the НССH, we suggest just one blueprint for such a regime which addresses several of the concerns raised above. Of course, different Ios will have distinct needs that should be reflected in any arbitral framework.

A Framework for Arbitrating Employment Disputes in Ios-The Hague Conference on Private International Law

A possible example for the use of arbitration by an Io are the Staff Rules Applicable to Officials and Personnel of the Hague Conference on Private International Law (HCCH Staff Rules). ${ }^{34}$ The HCC H Staff Rules are broadly based on those of the Organisation for Economic Co-operation and Development, but were changed in many regards to account for the very specific realities and requirements of the $\mathrm{HCCH} .{ }^{35}$ One significant change was the inclusion of an arbitration framework that governs certain employment disputes. It was included to provide a fast, efficient and cost-effective dispute resolution mechanism which provides just solutions as well as finality of outcome to the organization, its staff and, in limited circumstances, non-staff members. The HCCH Staff Rules were adopted by the Members of the $\mathrm{HCCH}$ and entered into effect on 1 January 2018. This section will now examine this form of dispute resolution under the following four headings: (i) The нссн Staff Rules-A Brief Introduction to Their Architecture; (ii) Dispute Resolution for HCCH Personnel; (iii) Availability of Arbitration for Others; and (iv) Costs not Addressed in the HCCH Staff Rules.

34 A redacted version of the HCCH Staff Rules can be found at <https://assets.hcch.net/ docs/fa7da3e6-fo5d-4721-84be-3da3b411bdod.pdf>accessed 23 November 2019. The rule relevant to this paper is Article 62 of the HCCH Staff Rules.

35 The HCCH is affiliated to the enlarged Co-ordinated Organizations. As the Introduction to the HсCH Staff Rules explains, "In 1963, the Member States of the HсCH decided to follow the Staff Regulations of the Organisation for Economic Co-operation and Development (OECD). Based on this decision, the Secretary General of the HCCH decided in 1979 to adopt the Staff Regulations of the OECD 'sous réserve des adaptations nécessaires' to account for the differences between the OECD and the HCCH". Over the years, a hotchpotch of directly and indirectly applied oEcD Regulations, Secretary General Decisions, but also practices and usages evolved. Transparency and clarity of the rules applicable to staff diminished over time. The efforts by the НСCH undertaken to rectify this resulted in the HCCH Staff Rules. 
5.1 The нссн Staff Rules - A Brief Introduction to Their Architecture

The нссн Staff Rules distinguish between two categories of staff. ${ }^{36}$ The first category is 'officials' who are appointed by instrument in accordance with Chapter 1, Article 2 of the нссн Staff Rules. The term 'official' is not defined. However, the HCCH Staff Rules provide that officials are all persons employed by the organization whose Letter of Appointment states that they are an official of the $\mathrm{HCCH}$.

In addition, the $\mathrm{HCCH}$ Staff Rules also include provisions for so-called 'personnel' of the organization. The term 'personnel' is quasi-defined by demarking this category of staff against officials. Article 47 stipulates that personnel include all persons engaged by the organization who are not appointed officials, and whose letter of engagement, as opposed to the instrument appointing an official, states that they are personnel of the нссн.

The difference between officials and personnel reflects the HCCH's approach to planning its human resources. Officials are the core of the HCCH's workforce. They are appointed to substantive positions, even if their initial appointment is temporally limited. ${ }^{37}$ Officials are paid from the budget of the $\mathrm{HCCH}$. Their roles and functions are required generally for the pursuit of the mandate, and strategic priorities, of the $\mathrm{HCCH}$. Personnel are engaged to pursue specific purposes or support defined projects. The salaries of personnel are paid from sources other than the organization's budget, that is, from voluntary contributions. The specifics of the engagement of personnel relevantly shapes the conditions for this category of staff. The relationship with the $\mathrm{HCCH}$ is governed in a separate Chapter of the нссн Staff Rules (Chapter 3 ). The terms of personnel are generally short and may only be longer than 24 months if exceptional circumstances require. ${ }^{38}$ Renewals are possible but only for a maximum term of 48 months. ${ }^{39}$ A term does not carry any expectation for renewal or conversion to the status of an official. ${ }^{40}$

36 The two categories of staff members engaged by the $\mathrm{HCCH}$ are those that are appointed by the Secretary General as 'officials', and those that are engaged as 'personnel'. The main difference is their role within the Permanent Bureau as explained below. The HCCH also engages consultants. These are not considered staff and their retainers are not governed by the $\mathrm{HCCH}$ Staff Rules but by individually agreed contracts. Article 11 of the HсCH Staff Rules provides the rules for limited and unlimited appointments as well as the conversion procedure.

38 HCCH Staff Rules, art 52.

39 Ibid., art 53.2.

$40 \quad$ Ibid., art 53.3. 


\subsection{Dispute Resolution for Hссн Personnel}

The dispute resolution procedure that applies to personnel can be found in Articles 62 and 63 of the HCCH Staff Rules, including the relevant Instructions. It is based on arbitration. In opting for arbitration as its dispute resolution procedure, the HCCH sought to balance the shortness of term of personnel with the obvious length and complexity of the dispute resolution procedure applicable to officials. The final resolution of a dispute through the Council of Europe Administrative Council after personnel had ended their term, was considered to be particularly troubling. Rather, the HCCH considered solutions that would avoid that as a result of lengthy procedures, disputes became entrenched beyond the term of personnel. A faster resolution of disputes was considered to promote access to justice for personnel and to bring quicker closure for the disputants. ${ }^{41}$ These policy considerations led to selecting arbitration as the preferred dispute resolution procedure for personnel. It is envisaged that arbitration will offer the HCCH as well as its personnel the anticipated fast, efficient and cost-effective dispute resolution procedure it was designed for.

Article 62.2 of the HCCH Staff Rules stipulates that personnel may have, under certain circumstances, access to what is called a 'simplified dispute resolution procedure. This simplified dispute resolution procedure is an arbitration procedure that is used to decide certain employment disputes. The circumstances in which this simplified dispute resolution procedure is available are defined in Articles 62.2(a) and 62.2(b) of the HCCH Staff Rules and they are connected to the length of the term of the member of the personnel. Firstly, in accordance with Article 62.2(a) of the HCCH Staff Rules, arbitration is the sole dispute resolution procedure available to personnel members whose engagement with the HCCH is less than, or equal to, 24 months. Especially considering the shortness of the term of this segment of personnel, the exclusive availability of arbitration should greatly facilitate the timely resolution of disputes, that is, within the term.

Second, arbitration is also available to those personnel who are engaged for a term longer than 24 months (and less than, or equal to, 48 months) if they choose this procedure. While Article 62.2(b) of the HCCH Staff Rules provides that these personnel are prima facie governed by the dispute resolution procedure that is available to officials, in accordance with Article 62.3 of the $\mathrm{HCCH}$ Staff Rules, they can choose arbitration as the preferred dispute resolution procedure. This choice was included as it was thought possible that longer-serving

41 Throughout this chapter, any references to underlying policy considerations are included only to the extent possible and are based on personal notes and the recollection of one of the authors. 
personnel may see benefits in having access to arbitration. It also gives expression to the principle of party autonomy in the context of the law of IOs. ${ }^{42}$

The basic rules set forth in Articles 62 and 63 of the НсCH Staff Rules are further reinforced through a set of detailed Instructions. Instruction 62.1 of the HCCH Staff Rules reinforces, in essence, the rules laid down in Article 62.2 of the Rules, but further clarifies that the simplified dispute resolution procedure is available to those personnel who have been aggrieved by an administrative act made by the Secretary General. Instruction 62.2 of the HCCH Staff Rules also reinforces the rule established by Article 63, repeating that personnel who have been aggrieved by a decision by an administrative act and serve for longer than 24 months (but less than, or equal to, 48 months) can choose a simplified dispute resolution process. Moreover, the Instruction further supplements the rule in Article 63 by stipulating that the parties may choose arbitration either at the time of the engagement of the personnel member, or may do so on an ad hoc basis, after a dispute has arisen. ${ }^{43}$ This approach was included to pursue two goals: firstly, to maximize flexibility in creating a relationship between the organization and its personnel that is most suited to the situation, and second, to ensure that personnel members and the нссн can choose this alternative dispute resolution mechanism to gain adequate access to justice at any stage of their term, even if no arbitration clause was included in their Letter of Engagement.

Instruction 62.4 of the $\mathrm{HCCH}$ Staff Rules then provides that arbitrations between personnel and the organization are to be conducted under the auspices of the Permanent Court of Arbitration (PCA) in The Hague. ${ }^{44}$ This includes that in accordance with Instruction 62.8 of the $\mathrm{HCCH}$ Staff Rules, the arbitration is to be conducted in accordance with the PCA's 'Optional Rules for Arbitration between International Organizations and Private Parties' (Optional Rules). ${ }^{45}$ Instruction 62.5 does provide that the personnel member's Letter of

42 The policy consideration involved, prima facie, the overarching principle that the length of the applicable dispute resolution procedure should be commensurate to the length of working with the $\mathrm{HCCH}$. This principle was then balanced with considerations relevant to access to justice, the rule of law and the equality of arms. This led to the inclusion of this choice: the overarching principle can give way to a personnel member's choice, a unilateral selection of arbitration as preferred dispute resolution procedure.

43 This policy was included in order to increase the flexibility of the availability of the procedure.

44 The seat of the Permanent Bureau of the HCCH is The Hague, so the choice of the PCA, also based in The Hague, was a natural one.

45 The fact that the PCA offers such dedicated rules was a further factor adding weight to choosing the PCA as central to the arbitration procedure for personnel members. The rules are available on the website of the PCA <https://pca-cpa.org/wp-content/uploads/ 
Engagement shall include a model arbitration clause as a jurisdictional basis for the arbitration.

When thought was given to devising a suitable arbitration clause, it was considered unnecessary to draft one from scratch if a suitable ready-made clause could be found. It was ultimately found in the form of the 'Model Arbitration Clauses for use in connection with the Permanent Court of Arbitration Optional Rules for Arbitration between International Organizations and Private Parties', comprising two model arbitration clauses, one used for existing, and one for future, disputes. ${ }^{46}$ The model arbitration clause for future disputes is included in the Letter of Engagement for personnel members engaged for a period of service of less than or equal to 24 consecutive months. It is also used for personnel members who are engaged for longer than 24 months (and less than, or equal to, 48 months) if they choose arbitration as their preferred dispute resolution procedure. If a dispute ensues, and the personnel and the $\mathrm{HCCH}$ wish to resolve it by arbitration, the model arbitration clause for existing disputes would be selected.

For the purpose of the Model Arbitration Clauses, Instruction 62.6 of the HCCH Staff Rules then stipulates certain parameters relevant to conducting the arbitration. ${ }^{47}$ Firstly, the Instruction provides that the arbitration is conducted by one arbitrator. This counters the default position in Rule 5 of the Optional Rules, according to which arbitrations should be heard by three arbitrators, and thus has been included to keep the costs for the resolution of disputes using arbitration as low as possible. Second, to avoid that the arbitrator needs to set the language of the arbitration in accordance with Rule 17 of the Optional Rules, which could result in argument, delay and with that further costs, arbitrations are to be conducted in English. Third, the HCCH opted for the Secretary General of the PCA as the appointing authority for the arbitration. Fourth, the seat of the arbitration is The Hague, the seat of the HCCH's Headquarters as well as of the PCA. Fifth, and most importantly, the agreement to arbitrate constitutes a waiver of any rights to immunity from execution, to which a party might otherwise be entitled with respect to the enforcement of any award rendered by an arbitral tribunal constituted pursuant to that agreement. This gives effect to Rule 1.2 of the Optional Rules according to which a

sites/6/2016/o1/Optional-Rules-for-Arbitration-Between-International-Organizationsand-Private-Parties-1996.pdf > accessed 23 November 2019.

$46 \quad$ PCA, 'Model Arbitration Clauses'.

47 These express rules, some of which modify default approaches suggested in the Optional Rules published by the PCA, seek to devise a system which balances considerations of speed, cost-efficiency and the equality of arms among the parties. 
waiver of immunity relating to the execution of an arbitral award must be explicitly stated. ${ }^{48}$

While Instruction 62.6 of the нсCH Staff Rules sets these parameters as default for the arbitration, there is a level of flexibility to accommodate any circumstances that may be encountered in practice. In accordance with Instruction 62.7 of the HCCH Staff Rules, the Secretary General may vary some of the parameters as appropriate. ${ }^{49}$ For example, the Secretary General may decide that the arbitration shall be heard by three arbitrators or that the arbitration shall be conducted in the other official language of the of the НСCH, namely French. The Secretary General may also choose a different appointing authority or select a seat of the arbitration other than The Hague. However, the Secretary General has not been given a similar discretion in relation to a waiver of any right to immunity from execution. Shielding this mandatory waiver from any discretion is consequent in light of the architecture of the dispute resolution procedure and to provide not only a fair procedure, but also a procedure the outcome of which can be enforced against the $\mathrm{HCCH}$, if required. This protects a fundamental aspect of providing personnel of the $\mathrm{HCCH}$ with appropriate access to justice.

\subsection{Availability of Arbitration for Others}

As mentioned above, the HCCH Staff Rules only govern officials and personnel of the organization. Other categories of persons providing services to the HCCH including, most notably, consultants, are not governed by the НСCH Staff Rules. However, Instruction 62.2(b) contains an important exception to this principle. This Instruction allows 'candidates' applying for appointments with the $\mathrm{HCCH}$ to trigger the arbitration procedure to complain of irregularities in the selection procedure. Within the HCCH Staff Rules, candidates are persons external to the $\mathrm{HCCH}$, who applied for a position with the $\mathrm{HCCH}$ through a competitive selection procedure and were short-listed, but who were ultimately not selected. The term 'candidates' is used in relation to both positions for officials and personnel and Instruction 62.2(b) should be read broadly to give access to arbitration for any candidate. If read this way, the

48 For the purpose of providing effective access to justice, the нссн considered it paramount to ensure the adequate enforcement of any award rendered by an arbitral tribunal. To put this issue beyond doubt, an express waiver was included in the НсCH Staff Rules.

49 These variations are thought to ensure maximum flexibility with regards to the procedure, without, however, compromising its certainty and effectiveness. 
exception broadens the group of those who have standing vis-à-vis the $\mathrm{HCCH}$, thus strengthening access to justice. ${ }^{50}$

\subsection{Costs Not Addressed in the нсcн Staff Rules}

Finally, it is worth mentioning that the HCCH Staff Rules do not include express provisions in relation to the costs of the arbitration. Thought was given to including such rules for they could help control the cost of the arbitration and to improve fairness as well as access to justice overall.

There was thought given to including a rule which would have capped the arbitrator's fees. The cap was to be set at EUR 5,000, with the fee payable in equal shares by the parties. The cap was to be subject to a discretion to increase the fee where the complexity of the dispute so required. To ensure adequate transparency, any increase needed to be discussed between the arbitrator and all parties, with the arbitrator required to propose a higher fee in clear and detailed terms.

A second rule pertaining to costs was also considered for inclusion, being designed to abrogate the general principle that costs follow the event. It was felt that this rule can increase parties' uncertainty in relation to the costs of dispute resolution and, if the uncertainty becomes particularly significant, may be detrimental to access to justice. Instead, it was considered to include a rule which mandated that each party was to cover its own legal costs. One issue that remained open was whether this rule should be absolute, or whether an arbitrator should have a very limited discretion to award costs, for example in circumstances of hardship.

These two rules on costs were conceived late in the development of the HCCH Staff Rules and ultimately did not find their way into the latter. Therefore, it was decided to include the two rules in the Letters of Engagement, or arbitrations pertaining to existing disputes, on a case-by-case basis. This prima facie gap ought to be addressed, for example by amending the Instructions in accordance with Article 64.3 of the HCCH Staff Rules. Overall, subject to some gaps, such as on the issue of costs, we suggest that the HCCH regime provides for a blueprint for IOs in terms of how to implement an arbitral framework. Of course, Ios based in different geographical locations may wish to use the services of arbitral institutions more proximate to them. However, the particularities of the HCCH regime are well suited to balance the interests of an IO and access to justice.

5o Extending the availability of the dispute resolution procedure to candidates is a direct reaction to the ECtHR's decision in ECtHR, Klauseckerv Germany 2015 (see para 76 therein for a more detailed discussion). 
Arbitration can, in principle, constitute an effective and desirable vehicle for IOs to comply with their access to justice obligations and ensure the delivery of justice to all those individuals working for Ios. However, if arbitration as a mode of dispute resolution is to succeed in providing a reasonable alternative to national courts, it must be implemented in good faith. Several matters need to be resolved. Some of these include ensuring certainty about the enforceability of awards by providing for express clauses in the contract of employment confirming that IOs' immunities have no role to play when it comes to the enforcement of arbitral awards; incorporating appropriate rules on appointment of arbitrators; and clearly prescribing how costs are to be allocated. Finally, through the example of the $\mathrm{HCCH}$, we provide just one blueprint for other international organizations. We consider the $\mathrm{HCCH}$ model, with appropriate adaptations, to be a useful model to implement a strong arbitral regime that protects individual rights as well as assists Ios in discharging their obligations to provide reasonable alternative means of dispute resolution.

\section{Reference List}

Caron D and others (eds), Practising Virtue: Inside International Arbitration (OUP 2016). Chadsey $v$ World Postal Union (now Universal Postal Union), ILOAT Judgment No 122 (1968).

CIArb, 'Arbitration' (CIArb) <https://www.ciarb.org/disputes/dispute-appointmentservice/arbitration/> accessed 1 March 2020.

Convention on the Privileges and Immunities of the United Nations (adopted on 13 February 1946, entered into force 17 September 1946) 1 UNTS 15 (General Convention).

Effect of Awards of Compensation Made by the United Nations Administrative Tribunal (Advisory Opinion) [1954] ICJ Rep 47.

Fox H and Webb P, The Law of State Immunity (3rd edn, OUP 2015).

Hague Conference on Private International Law, 'Staff Rules Applicable to Officials and Personnel of the Hague Conference on Private International Law' ( $\mathrm{HCCH}$, January 2018) <https://assets.hcch.net/docs/fa7da3e6-fo5d-4721-84be-3da3b411bdod.pdf> accessed 23 November 2019.

International Law Association, 'Berlin Conference (2004) Accountability of International Organisations' (2004) 1 International Organizations Law Review 221.

J.-D. M. v ILO, ILOAT Judgement No 2888 (2010).

Kidane L, The Culture of International Arbitration (OUP 2017).

Klausecker v Germany App No 415/o7 (ECtHR, 6 January 2015). 
Mansour S, 'Arbitration in rental agreement concluded with an international organization', Lebanese Arab and International Arbitration Review 34.

Menon S, 'The Transnational Protection of Private Rights Issues, Challenges, and Possible Solutions' (2015) 5 Asian Journal of International Law 2, 219.

Michaels R, 'Roles and Role Perceptions of International Arbitrators' in Mattli W and Dietz T (eds) International Arbitration and Global Governance: Contending Theories and Evidence (OUP 2014).

Obeid Law Firm, 'Arbitration and Immunity from Execution: a Bold Court Decision' (International Law Office, 10 April 2014) < https://www.internationallawoffice.com/ Newsletters/Arbitration-ADR/Lebanon/Obeid-Law-Firm/Arbitration-and-immunity-from-execution-a-bold-court-decision> accessed 23 July 2018.

Permanent Court of Arbitration, Labour Law Beyond Borders: ADR and the Internationalization of Labor Dispute Settlement (Kluwer Law International 2003).

Permanent Court of Arbitration, 'Model Arbitration Clauses for use in connection with the Permanent Court of Arbitration Optional Rules for Arbitration between International Organizations and Private Parties' < https://pca-cpa.org/wp-content/ uploads/sites/6/2016/o2/Model-Arbitration-Clauses-for-Use-in-Connection-withthe-Permanent-Court-of-Arbitration-Optional-Rules-for-Arbitration-between-In ternational-Organizations-and-Private-Parties.pdf $>$ accessed 1 March 2020.

Permanent Court of Arbitration, Optional Rules for Arbitration between International Organizations and Private Parties <https://pca-cpa.org/wp-content/uploads/sites /6/2016/o1/Optional-Rules-for-Arbitration-Between-International-Organizationsand-Private-Parties-1996.pdf $>$ accessed 23 November 2019.

Stone Sweet A and Grisel F, 'The Evolution of International Arbitration: Delegation, Judicialization, Governance' in Mattli W and Dietz T (eds), International Arbitration and Global Governance: Contending Theories and Evidence (OUP 2014).

Stone Sweet A and Grisel F, The Evolution of International Arbitration:Judicialization, Governance, Legitimacy (oup 2017).

Teixeira $v$ The Secretary-General of the United Nations, UN Administrative Tribunal Judgement No 230 (1977).

United Nations, Administrative Instruction on Consultants and Individual Contractors (19 December 2013) UN Doc ST/AI/2013/4, annex I (General Conditions of Contracts for the Services of Consultants and Individual Contractors).

United Nations, 'Administration of Justice at the United Nations, Report of the Secretary-General' (16 September 2010) UN Doc A/65/373.

United Nations, 'Review of the efficiency of the administrative and financial functioning of the United Nations, Report of the Secretary-General' (24 April 1995) UN Doc $\mathrm{A} / \mathrm{C} .5 / 49 / 65$.

UNESCO v Boulois, Court of Appeal of Paris, 19 June 1998, Revue de l'arbitrage 343.

Waite and Kennedy $v$ Germany App No 26083/94 (ECtHR 18 February 1999). 